\title{
Çayır Üçgülü (Trifolium pratense L.) Hatlarının Samsun Koşullarında Bazı Tarımsal Özelliklerinin Belirlenmesi
}

\author{
Fatih ALAY $^{1}$ Necda ÇANKAYA ${ }^{1} \quad$ Kadir İSPİLLI' ${ }^{1}$ \\ ${ }^{1}$ Karadeniz Tarımsal Araştırma Enstitüsü, Samsun \\ $\triangle$ : fatih.alay@tarim.gov.tr
}

Geliş (Received): 02.11.2017

Kabul (Accepted): 15.12.2017

\begin{abstract}
ÖZET: Bu araştırma. ümitvar çayır üçüulü hatlarının Samsun koşullarında bazı tarımsal özelliklerinin belirlenmesi amacı ile 2012-2014 yılları arasında yürütülmüştür. Araştırma materyalleri olarak 6 ümitvar hat ve 2 standart çeşit (Dadaş ve Tavlaş) kullanılmıştır. Deneme Karadeniz Tarımsal Araştırma Enstitüsü Çarşamba ve Bafra deneme alanlarında tesadüf blokları deneme desenine göre üç tekerrürlü olarak yürütülmüştür. Araştırma sonuçlarına göre en yüksek kuru ot ve tohum verimi (sırasıyla $1499.4 \mathrm{~kg}$ da-1 ve $46.6 \mathrm{~kg}$ da-1) ÇYR01-11 nolu hattan elde edilmiştir. Ortalama ham protein oranları \% 18.6-19.3. ADF oranları \% 41.8-43.3. NDF oranları ise \% 51.3-53.5 arasında değişmiştir. Bu sonuçlara göre ot ve tohum verimi standart olarak kullanılan çeşitlerden ve diğer hatlardan daha yüksek olan ÇYR01-11 nolu hattın. ADF ve NDF oranını azaltıcı ve HP oranını iyileştirici olarak Dadaş ve Tavlaş çeşitlerinin ıslah çalışmalarında kullanılmaya devam edilmesi yararlı olacaktır.

Anahtar Kelimeler: Çayır üçgülü (Trifolium pratense L.), kuru ot verimi, tohum verimi, ham protein oranı, ADF ve NDF oranı
\end{abstract}

\section{Determination of Some Agricultural Characteristics of Red Clover (Trifolium pratense L.) Lines Under Samsun Ecological Conditions}

\begin{abstract}
This study was carried out with the aim of determination of some agricultural properties of red clover promising lines under Samsun ecological conditions between 2012-2014. In research. Six promising lines and two standard varieties (Dadaş and Tavlaş) were used. The trial was carried out in three replications according to the randomized blocks trial design at the Black Sea Agricultural Research Institute at the locations of Çarşamba and Bafra. In this study, the highest dry hay yield (1499.4 kg da-1) and the highest seed yield (46.6 kg da-1) were obtained from ÇYR01-11 line. Mean crude protein. ADF and NDF ratios were 18.6-19.3\%. 41.8-43.3\% and 51.3$53.5 \%$ respectively. In the light of these results. ÇYR01-11 line that hay and seed yields were higher than the other genotypes is highly promising. Breeding studies especially decreasing of ADF and NDF ratios and improving of crude protein ratio should continue on this line.

Key words: Red clover, hay yield, seed yield, crude protein ratio, ADF and NDF ratio
\end{abstract}

\section{GİRIŞ̧}

Dünya genelinde yaşanan en büyük sorunlardan birisi; doğal kaynakların uygun ve etkili bir şekilde kullanılmaması ve artan dünya nüfusunun yeterli ve dengeli bir şekilde beslenememesidir. Beslenmenin en önemli girdilerinden biri de kırmızı et üretimi yani büyük ve küçükbaş hayvan hayvanlardan elde edilen kırmızı ettir. 44 milyon küçükbaş ve 14.3 milyon adet büyükbaş hayvan varlığımızın (Anonim. 2016a) beslenmesi büyük ölçüde doğal çayır-meralar, yem bitkileri, bitki artıkları, anızlar, sap saman gibi yemlere bağlıdır.

Yem bitkileri, hayvansal üretimin en önemli girdilerinden biri olan kaliteli kaba yemi sağlamasının yanı sıra, toprakların fiziksel ve kimyasal özelliklerine. kendisini takip eden kültür bitkilerinin verim ve kalitesine olumlu yönde etki etmektedir (Kuşvuran ve ark.. 2011; Açıkgöz ve ark.. 2002). Bununla birlikte ucuz ve kaliteli kaba yem olması, hayvanların mide mikroflorası için gerekli besin maddelerini içermesi, vitamin ve minerallerce zengin olması, hayvanların üreme gücünü artırması ve yüksek kalitede hayvansal ürün sağlaması bakımından hayvan beslemede önemlidir (Serin ve Tan. 2001a). Yem bitkileri içerisinde çok önemli yere sahip olan Çayır üçgülünün tarımı dünyanın birçok bölgesinde uzun yıllardır yapılmaktadır. Ilıman kuşağın serin ve nemli bölgelerine yayılmış olan çayır üçgülü; otlatmaya, kuru ot üretimine, silo yemine, toprak islahına ve çiğnenmeye dayanıklı olması nedeniyle mera ve otlak tesislerinde yaygın olarak kullanılmaktadır.

Karadeniz Bölgesi'nde arazi varlığı az ve çok parçalı olduğundan çiftçiler ekonomik ömrü 2-3 yıl olan çayır üçgülünü ekim nöbetine girebilecek bir yem bitkisi olarak tercih etmektedirler (Acar ve Ayan. 2000). Çarşamba ve Bafra ovalarında sonbahar-erken ilkbahar dönemlerinde yükselen taban suyundan çayır üçgülü, kök derinliğinin birçok baklagil yem bitkisinden az olması nedeniyle, daha az etkilenmektedir. Ayrıca, çayır üçgülü tütünden boşalan yüzlek ve eğimli arazilerde rahatlıkla yetişebilen bir bitkidir (Aşc1 ve Acar. 2009).

$\mathrm{Bu}$ çalışma Karadeniz Tarımsal Araştırma Enstitüsü deneme alanlarında 'Karadeniz Yem Bitkileri Araştırmaları"' projesi kapsamında 6 ümitvar hat ve 2 standart çeşit (Dadaş ve Tavlaş) kullanılarak 2012-2014 yılları arasında yürütülmüştür. 


\section{MATERYAL ve METOT}

$\mathrm{Bu}$ araştırma. Samsun koşullarında Karadeniz Tarımsal Araştırma Enstitüsü Bafra ve Çarşamba deneme arazilerinde 2012-2014 yılları yetiştirme sezonunda yürütülmüştür. Çarşamba deneme alanı toprak bakımından killi tın, hafif alkali, fosfor bakımından çok yetersiz, potasyumca yetersiz, organik maddece orta, orta kireçli ve tuzsuz yapıya sahiptir. Bafra deneme alanı ise toprak bakımından killi tın, hafif alkali, fosfor bakımından yetersiz, potasyumca orta, organik maddece orta, orta kireçli ve tuzsuz yapıya sahiptir (Çizelge 1).

Çizelge 1. Deneme yerleri topraklarının bazı özellikleri

\begin{tabular}{|c|c|c|c|c|}
\hline & \multicolumn{2}{|c|}{ Çarşamba } & \multicolumn{2}{|c|}{ Bafra } \\
\hline Bünye & 96 & Killi Tın & 100 & Killi Tin \\
\hline $\mathrm{pH}$ & 7.35 & Hafif Alkali & 7.91 & Hafif Alkali \\
\hline $\mathrm{P}_{2} \mathrm{O}_{5}\left(\mathrm{~kg} \mathrm{da}^{-1}\right)$ & 2.00 & $\begin{array}{c}\text { Çok } \\
\text { Yetersiz }\end{array}$ & 8.84 & Yetersiz \\
\hline $\mathrm{K}_{2} \mathrm{O}\left(\mathrm{kg} \mathrm{da}^{-1}\right)$ & 55 & Yetersiz & 84 & Orta \\
\hline Organik $\mathrm{I}$ & 1.23 & Orta & 1.73 & Orta \\
\hline Kireç $\mathrm{CaCO}_{3} \quad(\%)$ & 6.8 & Orta kireçli & 6.53 & Orta kireçli \\
\hline Total tuz (\%) & 0.027 & Tuzsuz & 0.034 & Tuzsuz \\
\hline
\end{tabular}

(Anon.. 2012)

Çalışmanın yürütüldüğü Bafra İlçesinde gerek uzun yıllar gerekse 2012/2013 ve 2013/2014 yılı yağış değerleri Çarşamba ilçesi verilerine göre daha düşük olmuştur (Çizelge 2). Çizelge 2 incelendiğinde, yağış her iki yerde de 2012/2013 döneminde 2013/2014 döneminden daha yüksek olmuştur. Denemelerde materyal olarak 6 ümitvar hat(enstitü ıslah hatları) ve 2 standart çeşit (Dadaş ve Tavlaş)(Erzurum DATAEM tedarik) kullanılmıştır. Denemeler tesadüf blokları deneme desenine göre 4 tekerrürlü olarak kurulmuştur. Parsel boyutları $1.20 \mathrm{~m} \mathrm{X} 5 \mathrm{~m}=6 \mathrm{~m}^{2}$ 'dir. Her iki deneme alanında denemeler 13 Ekim 2012 tarihinde elle siraya ekilmiştir. Parsellerin yarısı ot diğer yarısı tohum verimi olarak değerlendirilmiştir.

Çizelge 2. 2012- 2014 yılları ve uzun yıllar Çarşamba ve Bafra İlçeleri iklim verileri

\begin{tabular}{|c|c|c|c|c|c|c|c|c|c|c|c|c|}
\hline Yerlar & \multicolumn{6}{|c|}{ Samsun-Çarşamba } & \multicolumn{6}{|c|}{ Samsun-Bafra } \\
\hline Yillar & \multicolumn{2}{|c|}{$2012 / 2013$} & \multicolumn{2}{|c|}{$2013 / 2014$} & \multicolumn{2}{|c|}{$\begin{array}{c}\text { Uzun Yillar } \\
\text { Ort. }\end{array}$} & \multicolumn{2}{|c|}{$2012 / 2013$} & \multicolumn{2}{|c|}{$2013 / 2014$} & \multicolumn{2}{|c|}{$\begin{array}{c}\text { Uzun Yillar } \\
\text { Ort. }\end{array}$} \\
\hline Aylar & $\begin{array}{l}\text { Aylık } \\
\text { Yağış } \\
\text { Ort. } \\
(\mathrm{mm})\end{array}$ & $\begin{array}{l}\text { Aylik } \\
\text { Sicak } \\
\text { Ort. } \\
\left({ }^{0} \mathrm{C}\right)\end{array}$ & $\begin{array}{l}\text { Aylık } \\
\text { Yağış } \\
\text { Ort. } \\
(\mathrm{mm})\end{array}$ & $\begin{array}{l}\text { Aylik } \\
\text { Sicak } \\
\text { Ort. } \\
\left({ }^{0} \mathrm{C}\right)\end{array}$ & $\begin{array}{l}\text { Aylık } \\
\text { Yağış } \\
\text { Ort. } \\
(\mathrm{mm})\end{array}$ & $\begin{array}{l}\text { Aylik } \\
\text { Sicak } \\
\text { Ort. } \\
\left({ }^{0} \mathrm{C}\right)\end{array}$ & $\begin{array}{l}\text { Aylik } \\
\text { Yağış } \\
\text { Ort. } \\
(\mathrm{mm})\end{array}$ & $\begin{array}{l}\text { Aylik } \\
\text { Sicak } \\
\text { Ort. } \\
\left({ }^{0} \mathrm{C}\right)\end{array}$ & $\begin{array}{l}\text { Aylik } \\
\text { Yağış } \\
\text { Ort. } \\
(\mathrm{mm})\end{array}$ & $\begin{array}{l}\text { Aylik } \\
\text { Sicak } \\
\text { Ort. } \\
\left({ }^{0} \mathrm{C}\right)\end{array}$ & $\begin{array}{l}\text { Aylık } \\
\text { Yağış } \\
\text { Ort. } \\
(\mathrm{mm})\end{array}$ & $\begin{array}{l}\text { Aylık } \\
\text { Sicak } \\
\text { Ort. } \\
\left({ }^{0} \mathrm{C}\right)\end{array}$ \\
\hline Eylül & 113.0 & 20.1 & 44.9 & 18.7 & 59.6 & 20.0 & 39.5 & 20.3 & 42.5 & 18.6 & 52.3 & 19.2 \\
\hline Ekim & 99.8 & 17.8 & 68.6 & 13.1 & 108.3 & 15.8 & 43 & 18.9 & 43.9 & 13.2 & 94.2 & 15.2 \\
\hline Kasım & 276.4 & 13.5 & 21.2 & 12.1 & 99.9 & 11.5 & 146 & 13.4 & 26.8 & 5.0 & 94.8 & 11.1 \\
\hline Aralık & 128.6 & 9.2 & 50.1 & 4.5 & 102.9 & 8.2 & 159.7 & 8.8 & 52.3 & 8.3 & 76.0 & 7.6 \\
\hline Ocak & 93.6 & 8.1 & 5.4 & 7.7 & 75.6 & 7.0 & 85.1 & 7.7 & 9.9 & 8.0 & 68.9 & 5.8 \\
\hline Şubat & 35.6 & 9.3 & 14.2 & 9.8 & 63.7 & 6.8 & 25.7 & 8.7 & 27.6 & 9.1 & 40.1 & 5.6 \\
\hline Mart & 71.6 & 10.2 & 41.5 & 12.2 & 58.9 & 8.5 & 104.8 & 9.6 & 32.2 & 11.9 & 62.2 & 7.2 \\
\hline Nisan & 64.2 & 12.5 & 16.8 & 16.8 & 54.9 & 11.4 & 41 & 12.5 & 17 & 16.6 & 32.3 & 10.9 \\
\hline May1s & 8.9 & 18.2 & 48.6 & 20.4 & 49.3 & 15.9 & 26.8 & 18.4 & 69.7 & 21.0 & 30.5 & 15.2 \\
\hline Haziran & 49.7 & 20.9 & 115.4 & 23.9 & 50.4 & 20.3 & 41.6 & 21.5 & 25.4 & 24.4 & 48.2 & 19.9 \\
\hline Temmuz & 43.6 & 22.8 & 46.4 & 24.7 & 32.2 & 23.4 & 46.4 & 23.1 & 36.3 & 25.0 & 46.8 & 22.8 \\
\hline Ağustos & 26.5 & 23.6 & 95.8 & 20.5 & 39.7 & 23.8 & 118.4 & 23.6 & 56.1 & 20.4 & 46.6 & 22.9 \\
\hline Ortalama & & 15.5 & & 15.4 & & 14.4 & & 15.5 & & 15.1 & & 13.6 \\
\hline Toplam & 1011.5 & & 568.9 & & 795.4 & & 878.0 & & 439.7 & & 692.9 & \\
\hline
\end{tabular}

(Anonim. 2016b)

Parsellerdeki yaş ot hasatları \% 25-50 çiçeklenme döneminde yapılmıştır. 2013 yılı Çarşamba'da 1. yaş ot hasadı 25 Mayıs. 2. yaş ot hasadı 5 Temmuz. 2014 yılında ise 1. yaş ot hasadı 15 Mayıs. 2. yaş ot hasadı 1 Temmuz tarihlerinde yapılmıştır. 2013 yılı Bafra'da 1. yaş ot hasadı 27 Mayıs. 2. yaş ot hasadı 8 Temmuz. 2014 yılı 1. yaş ot hasadı 20 Mayıs. 2. yaş ot hasadı 2 Temmuz tarihlerinde yapılmıştır. Hasat sonrası denemelerdeki parsellerden alınan 500'er gr'lik numuneler 48 saatte $70^{\circ} \mathrm{C}^{\prime}$ de etüvde sabit bir ağırlığa gelinceye kadar kurutulmuş ve tartılmıştır (Kaplan. 2013). Alınan örnekler ögütülmüş. $1 \mathrm{~mm}$ çapındaki elekten geçirilerek kalite analizine hazır hale getirilmiştir. Ham protein oranı (\%). ADF (\%) ve NDF (\%) gibi özellikler Foss NIR Systems Model 6500 Win ISI II v1.5 cihazında. IC-0904FE kalibrasyon programı kullanılarak belirlenmiştir (Hoy ve ark.. 2002). Araştırma sonucunda elde edilen bulgular. Düzgüneş ve ark. (1987)'ın bildirdiği yöntemlere uygun olarak MSTAT-C paket programı ile istatistik analizleri 
yapılmıştır. Ortalamalar arası farklılıklar DUNCAN çoklu karşılaştırma testi kullanılarak karşılaştırılmıştır (Steel ve ark.. 1997).

\section{BULGULAR ve TARTIŞMA}

Kuru Ot Verimi $\left(\mathrm{kg} d a^{-1}\right)$

Kuru ot verimi bakımından yapılan değerlendirmeye göre yıllar ve yerlere göre genotipler arasında önemli $(\mathrm{P}<0.01)$ farklılıklar belirlenmiş olup, kuru ot verimi 1125.1 (Dadaş) - 1499.3 (ÇYR01-11) kg da ${ }^{-1}$ aralığında değişmiştir (Çizelge 3). Elde edilen verilerin Kuşvuran ve ark. (2011) ve Avcıoğlu ve ark. (2009)'nın bulduğu değerlerle uyumlu olduğu belirlenmiştir. Genotiplerin kuru ot verimi yönünden yıllar arasındaki farklılık istatistiksel açıdan önemli bulunmazken. genotiplerin ortalaması olarak Çarşamba'dan Bafra'ya göre her iki yılda da daha yüksek kuru ot verimleri alınmıştır (Çizelge 3). İki yılın ortalaması alınarak değerlendirildiğinde. Çarşamba'dan Bafra'ya göre \%146.4 oranında daha yüksek kuru ot verimi alınmıştır. Çayır üçgülü serin ve nemli iklimlerden orijinini alan ve bu koşullarda yüksek verim alınabilen çok yıllık bir baklagil yem bitkisidir (Manga ve ark.. 2003). Denemede sulama uygulaması yapılmamıştır.

Cizelge 3. Bazı çayır üçüulü genotiplerinin kuru ot ve tohum verim değerleri $\left(\mathrm{kg} \mathrm{da}^{-1}\right)^{*}$

\begin{tabular}{|c|c|c|c|c|c|c|c|c|c|c|}
\hline \multirow[t]{3}{*}{ GENOTIP } & \multicolumn{5}{|c|}{ KURU OT VERIMMI $\left(\mathrm{kg} \mathrm{da}^{-1}\right)$} & \multicolumn{5}{|c|}{ TOHUM VERIMİ(kg da $\left.{ }^{-1}\right)$} \\
\hline & \multicolumn{2}{|c|}{2013} & \multicolumn{2}{|c|}{2014} & \multirow[b]{2}{*}{ Ort. } & \multicolumn{2}{|c|}{2013} & \multicolumn{2}{|c|}{2014} & \multirow[b]{2}{*}{ Ort. } \\
\hline & Bafra & $\begin{array}{l}\text { Çarşamb } \\
\mathbf{a}\end{array}$ & Bafra & $\begin{array}{l}\text { Çarşamb } \\
\text { a }\end{array}$ & & Bafra & $\begin{array}{l}\text { Çarşamb } \\
\text { a }\end{array}$ & Bafra & $\begin{array}{l}\text { Çarşamb } \\
\text { a }\end{array}$ & \\
\hline \begin{tabular}{|l|} 
ÇYR01-4 \\
\end{tabular} & $\begin{array}{l}837.0 \\
\mathrm{e}\end{array}$ & $\begin{array}{l}1793.5 \\
\text { bcd }\end{array}$ & $749.3 \mathrm{e}$ & $2179.0 \mathrm{ab}$ & $1389.7 \mathrm{a}$ & $32 \mathrm{jkl}$ & $60 \mathrm{bc}$ & $33.51-1$ & $31.25 \mathrm{jkl}$ & $39.2 \mathrm{bcd}$ \\
\hline \begin{tabular}{|l|} 
ÇYR01-5 \\
\end{tabular} & $\begin{array}{l}754.8 \\
e^{-}\end{array}$ & $\begin{array}{l}1953.0 \\
\text { abc }\end{array}$ & $576.5 \mathrm{e}$ & $2037.0 \mathrm{ab}$ & $\begin{array}{l}1330.3 \\
\text { abc }\end{array}$ & $27.75 \mathrm{j}-\mathrm{m}$ & $44 \mathrm{f}-1$ & $\begin{array}{l}31.75 \\
\mathrm{jkl}\end{array}$ & 34.75 h-k & $34.6 \mathrm{~d}$ \\
\hline \begin{tabular}{|l|} 
CYR01-7 \\
\end{tabular} & $\begin{array}{l}798.3 \\
\mathrm{e}\end{array}$ & $\begin{array}{l}1817.5 \\
\text { bcd }\end{array}$ & $562.0 \mathrm{e}$ & $2231.0 \mathrm{ab}$ & $1352.2 \mathrm{ab}$ & $45.75 \mathrm{e}-\mathrm{h}$ & $44.5 \mathrm{e}-1$ & $31.5 \mathrm{jkl}$ & $46.75 \mathrm{~d}-\mathrm{g}$ & $42.1 \mathrm{ab}$ \\
\hline ÇYR01-8 & $\begin{array}{l}723.3 \\
e^{-}\end{array}$ & $1863.3 \mathrm{a}-\mathrm{d}$ & $756.0 \mathrm{e}$ & $2033.5 \mathrm{ab}$ & \begin{tabular}{|l}
1344.0 \\
abc
\end{tabular} & $44.75 \mathrm{e}-1$ & $58 \mathrm{~cd}$ & $31.5 \mathrm{jkl}$ & $34.251-1$ & $42.1 \mathrm{ab}$ \\
\hline \begin{tabular}{|l|} 
ÇYR01-9 \\
\end{tabular} & $\begin{array}{l}744.5 \\
\mathrm{e}\end{array}$ & $1911.5 \mathrm{a}-\mathrm{d}$ & $895.8 \mathrm{e}$ & $2183.3 \mathrm{ab}$ & $1433.8 \mathrm{a}$ & $46.5 \mathrm{efg}$ & $44.5 \mathrm{e}-1$ & $31.5 \mathrm{jkl}$ & $34.5 \mathrm{~h}-\mathrm{k}$ & $39.3 \mathrm{bcd}$ \\
\hline \begin{tabular}{|l|} 
ÇYR01-11 \\
\end{tabular} & $\begin{array}{l}913.8 \\
\mathrm{e}\end{array}$ & $2013.0 \mathrm{ab}$ & $774.0 \mathrm{e}$ & $2296.8 \mathrm{a}$ & $1499.4 \mathrm{a}$ & 55.5 cde & $70 \mathrm{ab}$ & $29 \mathrm{j}-\mathrm{m}$ & $31.75 \mathrm{jkl}$ & $46.6 \mathrm{ab}$ \\
\hline DADAŞ & $\begin{array}{l}880.0 \\
\mathrm{e} \\
\end{array}$ & $\begin{array}{l}1950.3 \\
\text { abc }\end{array}$ & $745.3 \mathrm{e}$ & $925.0 \mathrm{e}$ & $1125.1 \mathrm{c}$ & $47.75 \mathrm{~d}-\mathrm{g}$ & $77.75 \mathrm{a}$ & $18 \mathrm{~m}$ & $18.5 \mathrm{~m}$ & $40.5 \mathrm{bc}$ \\
\hline \begin{tabular}{|l|} 
TAVLAŞ \\
\end{tabular} & $\begin{array}{l}857.3 \\
\mathrm{e}\end{array}$ & $1503.3 \mathrm{~d}$ & $716.0 \mathrm{e}$ & $1567.3 \mathrm{~cd}$ & $1160.9 \mathrm{bc}$ & $38.25 \mathrm{~g}-\mathrm{j}$ & $54.25 \mathrm{c}-\mathrm{f}$ & $23 \mathrm{~lm}$ & $25.25 \mathrm{klm}$ & $35.2 \mathrm{~cd}$ \\
\hline \begin{tabular}{|l|} 
Lok. Ort. \\
\end{tabular} & $\begin{array}{l}813.6 \\
\text { B }\end{array}$ & $1850.7 \mathrm{~A}$ & $721.8 \mathrm{~B}$ & $1931.6 \mathrm{~A}$ & & $42.3 \mathrm{~B}$ & $56.6 \mathrm{~A}$ & $28.7 \mathrm{C}$ & $32.1 \mathrm{C}$ & \\
\hline \begin{tabular}{|l|} 
Yil Ort. \\
\end{tabular} & & 332.1 & & 26.7 & & & $5 \mathrm{~A}$ & & $.4 \mathrm{~B}$ & \\
\hline $\mathrm{CV}(\%)$ & & & 3.4 & & & & 20 & & & \\
\hline LSD & $\begin{array}{l}\text { Y1llar: } \\
\text { Y11X } \\
\text { Y11XG } \\
306.9 *\end{array}$ & $\begin{array}{l}\text { ÖD. Yerler: } \\
\text { er: } 236.7 * \text {. } \\
\text { notip: } 306.9 \\
\text {.Y1lXYerX }\end{array}$ & $\begin{array}{l}65.9 * * * \\
\text { enotip: } 2 \\
* \text { Y YerXG } \\
\text { Genotip: }\end{array}$ & $\begin{array}{l}7.8^{*} \\
\text { enotip: } \\
35.6^{*}\end{array}$ & & $\begin{array}{l}\text { Y1llar: } 4.1 \\
\text { Y1lX Yer: } \\
\text { Y1lXGeno } \\
\text {.Y11XYerX }\end{array}$ & $\begin{array}{l}* * \text {. Yerler } \\
.8^{*} \text {. Genot } \\
\text { ip: } 8^{* * *} . \text { Y } \\
\text { Genotip: } 11\end{array}$ & $\begin{array}{l}4.1 * * \\
: 5.7 * * \\
\text { XGenoti } \\
4 * *\end{array}$ & Ö.D & \\
\hline
\end{tabular}

*Aynı sütunda aynı harfle gösterilen ortalamalar arasında 0.05 veya 0.01 düzeyinde farklılık yoktur.

* Ö.D: Önemli değil

Bu nedenle. Çarşamba'da özellikle ilkbahar ve yaz aylarındaki sıcaklık yağış dağılımı çayır üçgülünün isteklerine daha uygun olduğu için bu verim farklılığ ortaya çıkmış olabilir. Yı1 x genotip interaksiyonunun önemli bulunduğu çalışmada en yüksek verim $1539.5 \mathrm{~kg}$ $\mathrm{da}^{-1}$ ile 2014 yılında ÇYR01-9 nolu hattan alınmıştır. Y1l x yer interaksiyonu bakımından önemli farklılıkların bulunduğu çalışmada en yüksek verim $1931.5 \mathrm{~kg} \mathrm{da}^{-1}$ ile 2014 yılında Çarşamba'dan elde edilmiştir. Genotip x yer interaksiyonu incelendiğinde. ÇYR01-11 nolu hattan Çarşamba'da en yüksek verim $\left(2154.8 \mathrm{~kg} \mathrm{da}^{-1}\right)$ sağlanmıştır. Yıl $\mathrm{x}$ yer $\mathrm{x}$ genotip interaksiyonu incelendiğinde en yüksek verim $2296.7 \mathrm{~kg} \mathrm{da}^{-1}$ ile 2014 yılında Çarşamba'da ÇYR01-11 nolu hattan alınmıştır (Çizelge 3).

Tohum Verimi $\left(\mathrm{kg} \mathrm{da}^{-1}\right)$

Tohum verimi yönünden genotipler arasında önemli
$(\mathrm{P}<0.01)$ farklılıklar belirlenmiş olup. genotiplerin ortalama tohum verimi değerleri 34.56 (ÇYR01-5) 46.56 (ÇYR01-11) $\mathrm{kg} \mathrm{da}^{-1}$ aralığında belirlenmiştir (Çizelge 3). Elde edilen bu veriler Açıkgöz (2001). Çomaklı (1990) ve Avcığlu ve ark. (2009)'nın bildirdiği değerlerle uyumlu bulunmuştur. Ayrıca tohum verimi açısından yıllar ve deneme yerleri arasındaki farklılıklar ve interaksiyonları (yer $\mathrm{x}$ genotip hariç) önemli bulunmuştur. 2013 ve 2014 yıllarında genotiplerin ortalaması olarak deneme yerleri incelendiğinde, kuru ot veriminde olduğu gibi, iklim ve çevre koşulları çayır üçgülü için daha uygun olan Çarşamba'dan \% 24.9 daha fazla tohum verimi alınmıştır. Genotip ve yerlerin ortalaması olarak yıllar incelendiğinde 2013 yılında (49.4 $\left.\mathrm{kg} \mathrm{da}^{-1}\right) .2014$ yılına göre $\left(30.4 \mathrm{~kg} \mathrm{da}^{-1}\right)$ daha yüksek verim alınmıştır. $\mathrm{Bu}$ durum 2013 yılında düşen yağış miktarının 2014 yılında 
düşen yağış miktarının yaklaşık iki katı olmasıyla açıklanabilir. Y1l $\mathrm{x}$ genotip interaksiyonu incelendiğinde. en yüksek verim $62.7 \mathrm{~kg} \mathrm{da}^{-1}$ ile 2013 yılında ÇYR01-11 nolu hattan alınırken; Y1l x yer interaksiyonuna göre en yüksek verim $56.6 \mathrm{~kg} \mathrm{da}^{-1}$ ile 2013 yilında Çarşamba'dan elde edilmiştir.

Çizelge 4. Bazı çayır üçgülü genotiplerinin ADF. NDF ve HPO değerleri (\%)*

\begin{tabular}{|c|c|c|c|c|c|c|c|c|c|c|c|c|c|c|}
\hline \multirow[t]{2}{*}{ GENOTIP } & \multicolumn{5}{|c|}{ ADF(\%) } & \multicolumn{4}{|c|}{ NDF(\%) } & \multicolumn{5}{|c|}{ HPO(\%) } \\
\hline & \multicolumn{2}{|c|}{2013} & \multicolumn{2}{|r|}{2014} & \multirow[b]{2}{*}{ Ort. } & 2013 & \multicolumn{2}{|r|}{2014} & \multirow[b]{2}{*}{ Ort. } & \multicolumn{2}{|r|}{2013} & \multicolumn{2}{|r|}{2014} & \multirow[b]{2}{*}{ Ort. } \\
\hline & Bafra & Çarșamb: & \begin{tabular}{|l|l} 
a & Bafra \\
\end{tabular} & Carşamba & & \begin{tabular}{l|l} 
Bafra & Çarșamb
\end{tabular} & $\begin{array}{l}\text { a Bafra } \\
\end{array}$ & Çarşamba & & Bafra & Çarşamba & Bafra & Çarşamba & \\
\hline $\begin{array}{l}\text { YR01-4 } \\
\end{array}$ & $41.3 \mathrm{e}-1$ & $47.5 \mathrm{ab}$ & $\begin{array}{ll}43.2 & 0 \\
\mathrm{~g}\end{array}$ & $c-38.9 \mathrm{ij}$ & 42.7 & $50.3 \mathrm{~h}-159.2 \mathrm{a}$ & $52.3 \mathrm{f}-\mathrm{k}$ & $49.0 \mathrm{klm}$ & 52.7 & $19.1 \mathrm{c}-\mathrm{f}$ & $16.8 \mathrm{gh} 1$ & $16.1 \mathrm{hl}$ & $124.0 \mathrm{a}$ & 19.0 \\
\hline YR01-5 & $41.7 \mathrm{e}-1$ & $45.1 \mathrm{a}-\mathrm{d}$ & $\begin{array}{ll}44.1 & b \\
e\end{array}$ & $0-38.6 \mathrm{ij}$ & 42.4 & 50.8 g-156.5 a-d & $\begin{array}{ll}53.8 & \mathrm{c}- \\
\mathrm{g} & \end{array}$ & $48.0 \mathrm{~lm}$ & 52.3 & 17.9 e-h & $18.4 \mathrm{c}-\mathrm{g}$ & 15.71 & $22.8 \mathrm{a}$ & 18.7 \\
\hline ÇYR01-7 & $41.4 \mathrm{e}-1$ & $46.1 \mathrm{abc}$ & $\begin{array}{l}44.0 \\
\text { cde }\end{array}$ & $37.2 \mathrm{j}$ & 42.2 & $51.0 \mathrm{~g}-156.5 \mathrm{a}-\mathrm{d}$ & $\begin{array}{ll}53.6 & \mathrm{c} \\
\mathrm{h}\end{array}$ & $46.5 \mathrm{~m}$ & 51.9 & $18.4 \mathrm{c}-\mathrm{g}$ & 16.4 gh1 & $16.2 \mathrm{~h} 1$ & $3.8 \mathrm{a}$ & 18.7 \\
\hline ÇYR01-8 & $40.2 \mathrm{f}-\mathrm{j}$ & $46.1 \mathrm{abc}$ & $43.4 \mathrm{c}-$ & $-f 41.3 \mathrm{e}-1$ & 42.8 & $50.11-156.8 \mathrm{abc}$ & $53.1 \mathrm{e}-1$ & $151.3 \mathrm{~g}-1$ & 52.8 & $19.9 \mathrm{cde}$ & e16.6 gh1 & 15.81 & $22.8 \mathrm{a}$ & 18.8 \\
\hline YR01-9 & $40.7 \mathrm{e}-1$ & $47.7 \mathrm{a}$ & $\begin{array}{l}44.0 \\
\text { cde }\end{array}$ & $38.9 \mathrm{ij}$ & 42.8 & $50.21-158.8 \mathrm{ab}$ & $53.2 \mathrm{~d}-1$ & $147.9 \mathrm{~lm}$ & 52.5 & $19.5 \mathrm{cde}$ & e16.3 gh1 & $15.8 \mathrm{~h} 1$ & $22.9 \mathrm{a}$ & 18.6 \\
\hline ÇYR01-11 & $40.2 \mathrm{f}-\mathrm{j}$ & $45.7 \mathrm{a}-\mathrm{d}$ & $\begin{array}{l}46.2 \\
\mathrm{abc}\end{array}$ & $41.0 \mathrm{e}-1$ & 43.3 & $50.2 \mathrm{~h}-157.9 \mathrm{ab}$ & $55.4 \mathrm{~b}-\mathrm{f}$ & $\mathrm{f} 50.4 \mathrm{~g}-1$ & 53.5 & $20.4 \mathrm{bcd}$ & $\mathrm{d} 18.3 \mathrm{~d}-\mathrm{g}$ & 15.21 & 20.5 bcd & 18.6 \\
\hline$\overline{\text { DADAS }}$ & $41.0 \mathrm{e}-1$ & $45.1 \mathrm{a}-\mathrm{d}$ & $\begin{array}{ll}42.4 & d \\
h\end{array}$ & $\mathrm{~d}-38.7 \mathrm{ij}$ & 41.8 & 50.3 h-153.3 d-1 & $52.8 \mathrm{e}-\mathrm{j}$ & $\mathrm{j} 48.9 \mathrm{klm}$ & 51.3 & $19.7 \mathrm{cde}$ & e16.7 gh1 & $17.2 \mathrm{f}$ & $23.7 \mathrm{a}$ & 19.3 \\
\hline TAVLAŞ & $39.5 \mathrm{~h}-\mathrm{j}$ & $45.7 \mathrm{a}-\mathrm{d}$ & $\begin{array}{l}42.6 \mathrm{~d} \\
\mathrm{~h}\end{array}$ & $\mathrm{~d}-39.8 \mathrm{~g}-\mathrm{j}$ & 41.9 & $47.9 \operatorname{lm} 56.0$ a-e & $53.0 \mathrm{e}-1$ & $149.5 \mathrm{j}-\mathrm{m}$ & 51.6 & $20.5 \mathrm{bc}$ & 16.9 gh1 & $17.3 \mathrm{f}-$ & $22.3 \mathrm{ab}$ & 19.3 \\
\hline Yer Ort. & 40.7 & 46.1 & 43.7 & 39.3 & & 56.9 & 53.4 & 48.9 & & $19.4 \mathrm{~B}$ & $17.1 \mathrm{C}$ & $16.2 \mathrm{C}$ & $22.9 \mathrm{~A}$ & \\
\hline Yil Ort. & & $.4 \mathrm{~A}$ & & $41.5 \mathrm{~B}$ & & $53.5 \mathrm{~A}$ & & $1.2 \mathrm{~B}$ & & & $8.2 \mathrm{~b}$ & & $19.5 \mathrm{a}$ & \\
\hline $\mathrm{CV}(\%)$ & & & 5.7 & & & & 62 & & & & 7.8 & & & \\
\hline LSD & $\begin{array}{l}\text { Y1llar: } 1 \\
\text { Y11X Ye } \\
\text { Y11XGe } \\
\text { Ö.D .Y1 }\end{array}$ & $\begin{array}{l}.9 * \text { Yerl } \\
\text { er: } 2.8 * * * \\
\text { notip: Ö.I } \\
\text { IXYerXG }\end{array}$ & $\begin{array}{l}\text { er: Ö.D } \\
\text { Genot } \\
\text { D. YerX } \\
\text { senotip: }\end{array}$ & $\begin{array}{l}\text { ip: Ö.D } \\
\text { KGenotip: } \\
\text { Ö.D }\end{array}$ & & $\begin{array}{l}\text { Y1llar: 1.6*. Yerl } \\
\text { Y1lX Yer: 2.2** } \\
\text { Y11XGenotip: Ö. } \\
\text { Ö.D .Y11XYerXC }\end{array}$ & $\begin{array}{l}\text { ler: Ö.D } \\
\text { k. Genoti } \\
\text { D. YerX } \\
\text { Genotip: }\end{array}$ & $\begin{array}{l}\text { ip: Ö.D } \\
\text { XGenotip: } \\
\text { Ö.D }\end{array}$ & & $\begin{array}{l}\text { Yillar: } 0 \\
\text { YilX Ye } \\
\text { YilXGe } \\
\text { YerXGe } \\
\text { YilXYe }\end{array}$ & $\begin{array}{l}0.9 * \text { Yerler } \\
\text { er: } 1.2^{* * *} \\
\text { notip: } 1.5^{*} \\
\text { enotip:Ö.D } \\
\text { rXGenotip: }\end{array}$ & $\begin{array}{l}: 0.9 * * \\
\text { Genotip } \\
* . \\
\text { Ö.D }\end{array}$ & p: Ö.D & \\
\hline
\end{tabular}

*Aynı sütunda aynı harfle gösterilen ortalamalar arasında 0.05 veya 0.01 düzeyinde farklılık yoktur.

* Ö.D: Önemli değil.

\section{ADF (\%)(Asit Deterjanda Çözünmeyen Lif). NDF (\%) (Nötr Deterjanda Çözünmeyen Lif). HPO(\%) (Ham Protein Orani) \\ ADF(\%)(Asit Deterjanda Çözünmeyen Lif)}

ADF bakımından yapılan değerlendirmeye göre, yıllar ve yerlere göre genotipler arasında önemli farklılık bulunmazken, yalnızca yıllar arasındaki farklılık ve yıl x yer interaksiyonunun önemli olduğu belirlenmiştir (Çizelge 4). 2013 y1lında (\% 43.4). 2014 yılına göre $(\% 41.5)$ genotiplerin ortalama ADF oranları daha yüksek olmuştur. Y1l $x$ yer interaksiyonu incelendiğinde en yüksek ADF oranı \% 46.1 ile 2013 yılında Çarşamba'da belirlenmiştir. Yer ve yılların ortalaması olarak genotiplerin ADF oranları \% 41.7 (Dadaş) - \% 43.2 (ÇYR01-11) aralığında bulunmuştur. Elde edilen değerler (Tavlaş ve ark.. 2009; Yavuz ve ark.. 2012)'nın bildirdiğinden yüksektir. Bu durum genotip ve iklim koşullarındaki farklılıklardan kaynaklanmış olabilir. Nitekim 2013 y1lı 2014 yılına göre özellikle Bafra'da daha sıcak geçmiştir (Çizelge 2). Genotiplerin deneme yerlerinde yıllara göre değişen iklim koşullarına gösterdikleri tepkinin farklı olması nedeniyle de y1lxyer interaksiyonu önemli bulunmuştur.

\section{NDF (\%) (Nötr Deterjanda Çözünmeyen Lif)}

NDF yönünden yapılan değerlendirmeye göre, yalnızca yıllar arasındaki farklılık ve yılxyer interaksiyonunun önemli olduğu belirlenmiştir (Çizelge 4). 2013 y1lında (\% 53.4). 2014 yılına göre (\% 51.1) genotiplerin ortalama NDF oranları daha yüksek olmuştur. Yılxyer interaksiyonu incelendiğinde en düşük NDF oranı \% 56.8 ile 2013 yılında Çarşamba'da en yüksek ise \% 48.9 olarak 2014 y1lında yine Çarşamba'da belirlenmiştir. Yıllar arasındaki farklılık yıllara göre değişen iklim koşullarından yer $x$ yıl interaksiyonunun önemli çıkması ise. genotiplerin deneme yerlerinde yıllara göre değişen iklim şartlarına gösterdikleri tepkinin farklı olmasından kaynaklanmış olabilir.

\section{HPO (\%)(Ham Protein Orani)}

HP oranları incelendiğinde. genotipler arasında önemli bir farklılık bulunmazken, deneme yerleri ve yıllar arasındaki farklılık ile yıl x yer ve yıl x genotip interaksiyonunun önemli olduğu belirlenmiştir (Çizelge 4). Yılların ortalaması incelendiğinde 2014 yılında (\% 19.5) 2013 y1lına (\% 18.2) göre daha yüksek ortalama HP oranı tespit edilmiştir. Çarşamba (\% 19.9)'da. Bafra (\%17.7)'ya göre HP oranının \% 12.3 daha fazla olduğu belirlenmiştir. Y1l x yer interaksiyonu incelendiğinde en yüksek HP oranı \% 22.8 olarak 2014 yılında Çarşamba'da saptanmıştır. Y1l x genotip interaksiyonu incelendiğinde en yüksek HP oranı \% 20.4 ile 2014 yılında Dadaş çeşidinde belirlenmiştir (Çizelge 4). Genotiplerin HP oranları \% 18.6 (ÇYR01-11) - \% 19.3 (Dadaş) aralığında belirlenmiştir. Elde edilen değerler Tavlas ve ark. (2009) ve Yavuz ve ark. (2012)'na göre yüksek. Acar ve Aşçı (2006) ile Sincik ve ark. (2002) ile uyumludur. Bulgular arasındaki bu farklılığın araştırmalarda kullanılan genotip, iklim faktörleri, biçim 
zamanları ve dönemlerinin farklılı̆̆ından kaynaklandığını söylemek mümkündür. Nitekim Linn ve Martin (1999), bitki tür ve çeşitlerinin yem kalitesi bakımından büyük değişkenlik gösterdiğini, sıcaklık, 1şık ve yağış gibi çevresel faktörler ve iklim şartlarının gelişme boyunca ve hasatta kaliteyi etkileyebildiğini. Belyea ve ark. (1999), yemin içeriğinin yıllar itibariyle değiştiğini bildirmişlerdir.

\section{SONUÇ}

Sonuç olarak; en yüksek kuru ot ve tohum verimi ÇYR01-11 nolu hattan elde edilirken, en düşük ADF, NDF oranları ve en yüksek HP oranları Dadaş ve Tavlaş çeşitlerinden elde edilmiştir. Bu sonuçlara göre, ÇYR01-11 nolu hattın ADF, NDF oranını azaltmak ve HP oranını yükseltmek için Dadaş ve Tavlaş çeşitleri ıslah çalışmalarında kullanılmaya devam edilebilir

\section{KAYNAKLAR}

Acar Z, Ayan İ 2000. Yem Bitkileri Kültürü. Ondokuzmayıs Üniversitesi, Zir. Fak. Ders Kitabı, No: 2, Samsun, 152s.

Acar Z, Aşçı Ö 2006. Ondokuzmayıs Üniversitesi. Zir. Fak. Dergisi J. of Fac. of Agric.. 21(3):323-329.

Açıkgöz E, Turgut İ, Filya İ 2002. Silaj Bitkileri Yetiştirme ve Silaj Yapımı. Hasad Yayıncılık.

Açıkgöz E 2001. Yem Bitkileri. Uludağ Üniversitesi. Ziraat Fakültesi, Tarla Bitkileri Bölümü, 3. Bask1, Bursa, 68-74s.

Anonim 2016a. Bitkisel istatistik verileri. https://biruni.tuik.gov.tr/bitkiselapp/bitkisel.zul (Erişim tarihi 01.08.2017).

Anonim 2012. Karadeniz Tarımsal Araştırma Enstitüsü. Toprak Bölümü Laboratuarı. Samsun

Anonim 2016b. Meteoroloji 10. Bölge Müdürlüğü. Samsun

Aşçı Ö, Acar Z 2009. Bazı Arkadaş Bitkilerin Çayır Üçgülü'nün Fide Gelişimi, Ot Verimi, Yabancı Ot Rekabeti ve Diğer Bazı Özelliklerine Etkisi. OMÜ, Fen Bil. Ens.. Tarla Bitkileri ABD, Doktora Tezi (Basılmamış), 122s.

Avcıoğlu R, Hatipoğlu R, Karadağ Y 2009. Tarım ve Köyişleri Bakanlığı Tarımsal Üretim ve Geliştirme Genel Müdürlüğü. Cilt: 2, İzmir, 353-358s.

Belyea R, Rrestrepo R, Martz F, Ellersieck M 1999. Effect of Year and Cutting on Equations for of Dairy
Science Estimating Net Energy of Alfalfa. Journal. 82(9).1943-1949.

Çomaklı B 1990. Sulu Şartlarda Yetiştirilen Çayır Üçcülü (Trifolium pratense L.)'ne Uygulanan Farklı Sira Aralığı, Sulama Seviyesi ve Fosforla Gübrelemenin Tohum ve Sap Verimi İle Bazı Verim Unsurlarına Etkileri. Atatürk Ü. Zir. Fak. Der., 21(1).43-59s.

Düzgüneş O, Kavuncu O, Kesici T, Gürbüz F 1987. Araştırma ve Deneme Metotları (İstatistik-II). A.O.Z.F. Yay, Ankara, 1021. 381s.

Hoy MD, Moore KJ, George JR, Brummer EC 2002. Alfalfa Yield And Quality As İnfluenced By Establishment Metod. Agr. J.. 94. 65-71.

Kaplan M 2013. Yaygın Fiğ (Vicia sativa L.) Genotiplerinde Hasat Zamanının Ot Verim Ve Kalitesine Etkisi. Erciyes Üniversitesi, Fen Bilimleri Enstitüsü Dergisi, 29(1):76-80.

Kuşvuran A, Nazlı Rİ, Tansı V 2011. Türkiye'de ve Batı Karadeniz Bölgesi'nde Çayır-Mera Alanları, Hayvan Varlığı ve Yem Bitkileri Tarımının Bugünkü Durumu. GOÜ. Ziraat Fakültesi Dergisi, 28(2): 21-3221.

Linn JG, Martın NP 1999. Forage Quality Tests And Interpretations.

www.extension.umn.edu/distribution/livestocksyste ms/ID2637.html

Manga İ, Acar Z, Ayan İ 2003. Baklagil Yembitkileri. OMÜ Ziraat Fakültesi Ders Kitabı, No: 7 (Genişletilmiş II. Bask1), Samsun. 451s.

Serin Y, Tan M 2001a. Yem Bitkileri Kültürüne Giriş. Atatürk Üniversitesi, Ziraat Fakültesi Yayınları, No: 206, 217 s.

Sincik M, Bilgili U, Uzun A, Açıkgöz E 2002. Farklı Azot Ve Fosfor Dozlarının Ak Üçgül (Trifolium repens L.)'de Ot Ve Tohum Verimi İle Bazı Verim Ve Kalite Komponentleri Üzerine Etkileri. Uludağ. Üniv. Zir. Fak. Derg.. 6(2): 127-36.

Steel RGD, Torrie JA, Dickey DA 1997. Principles and Procedures of Statistics. A. Biometrical Approach 3rd Edi. Mc Graw Hill Book.INC.N.Y.

Tavlas A, Yolcu H, Tan M 2009. African Journal of Agricultural Research Vol. 4 (7):633-641.

Yavuz T, Sürmen M, Albayrak S, Çankaya N 2012. Turkish Journal of Field Crops. 17(1): 46-50. 